\title{
Stone Alkaline Water Induces Apoptosis of Prostate Cancer Cells and Inhibits Tumor Cell Induced Angiogenesis In Vitro
}

\section{Running Title: Stone Alkaline Water Inhibits Prostate Cancer Progression In Vitro}

Sila Appak-Baskoy ${ }^{1}$, Iknur Kulcanay Sahin ${ }^{2}$, Ozgun Teksoy ${ }^{3}$, Mustafa Cengiz $^{4}$, Asuman Deveci Ozkan $^{5}$, Gamze Guney Eskiler ${ }^{5}$, Namık Bilici ${ }^{6}$, Pinar Oztopcu-Vatan ${ }^{3}$, Yılmaz Altuner ${ }^{7}$, Adnan Ayhanci $^{3}$

${ }^{1}$ Ryerson University, Faculty of Science and Institute for Biomedical Engineering, Science and Technology (IBEST), Toronto, Ontario, Canada

${ }^{2}$ Kırıkkale University, Vocational School of Health Services, Kırıkkale, Turkey

${ }^{3}$ Eskisehir Osmangazi University, Faculty of Science and Arts, Department of Biology, Eskisehir, Turkey

${ }^{4}$ Siirt University, Faculty of Education, Department of Elementary Education, Siirt, Turkey

${ }^{5}$ Sakarya University, Department of Medical Biology, Faculty of Medicine, Sakarya, Turkey

${ }^{6}$ Karabuk University Department of Medical Pharmacology, Faculty of Medicine, Karabuk, Turkey

${ }^{7}$ Karabuk University Department of Obstetrics, Faculty of Health Sciences, Karabuk, Turkey

Correspondence :

Prof Adnan Ayhanci (PhD)

Eskisehir Osmangazi University

Department of Biology

Meselik 26480 Eskisehir TURKEY

Phone: +902222393750

E mail: aayhanci@ogu.edu.tr 


\section{Abstract}

Treatment options to improve overall survival rate of prostate cancer patients are limited since tumor cells acquire resistance to the chemotherapeutic drugs. We aimed to determine anticancer effects of stone alkaline water (SAW) on PC-3 and DU-145 prostate adenocarcinoma cell lines. SAW was obtained by triturating high stones under vacuum at $3000{ }^{\circ} \mathrm{C}$. High mineral and trace element containing fraction of SAW was used for the experiments. Viability of the tumor cells was analyzed using tetrazolium based WST-1 cell proliferation assay, cell cycle analysis was carried out with Propidum lodide staining (Muse ${ }^{\mathrm{TM}}$ Cell Cycle Kit). Acridine Orange and Annexin $\mathrm{V}$ stainings were done to analyze the cellular morphology and to determine apoptosis. Tumor cell derived angiogenesis was analyzed with migration and tube formation assays. SAW treatment resulted in accumulation of cells at G0/G1 phase and inhibited tumor cell induced HUVEC tube formation and migration. SAW treatment significantly decreased viability of PC-3 and DU-145 prostate adenocarcinoma cells and induced apoptotic cell death. Intriguingly, treatment of the prostate cancer cells with SAW inhibited tumor cell derived angiogenesis. SAW may aid in treating prostate cancer and molecules important for SAW'S apoptotic and anti-angiogenic effects need to be determined.

Key Words: Prostate Cancer; Stone Alkaline Water; Apoptosis; Angiogenesis, Tumor

\section{Introduction}

Prostate cancer is the second most common cancer, as well as, the second leading cause of mortality among males in the world [1]. Although studies on lifestyle factors that promote formation of the prostate cancer show promising results, the etiology of prostate cancer is still unclear as there is no specific carcinogenic substance found to be responsible of the disease 
formation [2]. Reports indicate that prostate cancer manifests itself as a result of genetic factors as well as lifestyle, diet, social and environmental factors $[3,4,5]$. Although surgery, radiotherapy and chemotherapy improve overall survival, most of the patients develop resistance against the chemotherapeutic drugs and tumor progresses with metastasis. The survival of patients with metastatic prostate cancer remains very low and new alternative therapeutic strategies are urgently needed to inhibit tumor progression.

Water is a liquid substance and contains various minerals and thus has significant role in human health. The chemical polarity of water and the ability to form hydrogen bonds are its most important characteristics. Stone alkaline water (SAW) is a high alkaline mineral water which is obtained by breaking certain stones under high heat, pressure and vacuum. The atomic absorption analysis (Table 1) shows that SAW contains variety of different minerals, mainly magnesium (Mg), calcium (Ca), sodium ( $\mathrm{Na})$ and carbonate $\left(\mathrm{CO}_{3}\right)$.

$\mathrm{Mg}$ and $\mathrm{Ca}$ are reported to protect cells against cancer $[6,7]$. Mg prevents DNA damage caused by different carcinogenic agents [8]. In some studies, researchers have demonstrated that the level of $\mathrm{Ca}$ and $\mathrm{Mg}$ in water has a preventive effect on colorectal and gastric cancers [9-11]. In the literature, alkaline water or mineral water has been shown to have beneficial effects on human health [12-16]. Nevertheless, there is a lack of evidence whether SAW and its mineral and trace element content has anti-cancer effects or not. Thus, the aim of this study is to examine the potential anti-cancer and apoptotic effects of SAW on metastatic prostate cancer cell lines PC-3 and DU-145 and how it affects tumor cell induced angiogenesis, in vitro. 


\section{Material and Methods}

\section{SAW}

Stones with high carbonate content are washed and dried and then milled and sieved. The sieved stones were triturated under vacuum at $3000{ }^{\circ} \mathrm{C}$ after treating them with acid. A high mineral and trace element containing fraction of SAW was obtained by irrigating the stone powder a few hours. Gathered SAW was placed in transparent glass bottles and stored at room temperature.

\section{Cell Culture}

PC-3 and DU-145 cells were purchased from the American Type Culture Collection (ATCC).

Prostate tumor cells were incubated in Roswell Park Memorial Institute-1640 (RPMI-1640, Thermo) medium whereas HUVECs were maintained in DMEM medium with $10 \%$ heatinactivated fetal bovine serum (FBS, Gibco) and 1\% penicillin/streptomycin (Gibco). Cells were cultured in a humidified $37{ }^{\circ} \mathrm{C}$ incubator (Thermo Fisher Scientific) with $5 \% \mathrm{CO}_{2}$. Both cells were counted using Countes II Cell Counter (Thermo Fisher Scientific, USA) for further analysis.

\section{WST-1 Analysis}

In order to analyze the proliferation of the cells with/without SAW treatment tetrazolium based WST-1 cell proliferation assay was performed. Briefly, PC-3, DU-145 cells and HUVECs $\left(2 \times 10^{4}\right.$ cells/well) were cultured in 96-well plates, then treated with different SAW concentrations (0.5$10 \mathrm{mg} / \mathrm{mL}$ ) for 24 and $48 \mathrm{~h}$. After incubation, cells were stained with $10 \mu \mathrm{L}$ of WST-1 reagent (Biovision) at $37^{\circ} \mathrm{C}$ for 30 minutes in the dark and analyzed at $450 \mathrm{~nm}$ with 96 -well plate reader (Allsheng, China). Each experiment was performed three times. We selected the most effective 
concentrations (1 and $2.5 \mathrm{mg} / \mathrm{mL}$ ) of SAW and exposure time $(24 \mathrm{~h})$ for further experiments such as Annexin V, Acridine Orange stainings and cell cycle analysis.

\section{Annexin V Analysis}

In order to show the possible apoptotic effect of SAW, Annexin V analysis was carried out. For this purpose, PC-3, DU-145 cells and HUVECs ( $1 \times 10^{5}$ cells/well) were cultured in six-well plates for $24 \mathrm{~h}$ and treated with 1 and $2.5 \mathrm{mg} / \mathrm{mL}$ of SAW for $24 \mathrm{~h}$ with fresh medium. After treatment, the cells were washed twice with cold phosphate buffer (PBS) after centrifugation at 2000x $g$ for 5 minutes. Cells were stained with Muse ${ }^{\mathrm{TM}}$ Annexin V \& Dead Cell Assay kit (Millipore) and incubated for 30 minutes at room temperature in dark conditions. At the end of incubation cells were analyzed using the Muse ${ }^{\mathrm{TM}}$ Cell Analyzer (Millipore). Each experiment was performed in three replicates for each of the cell line.

\section{Cell Cycle Analysis}

For the cell cycle analysis, Propidum lodide based nuclear staining was carried out according to the manufacturer's protocol. Briefly, PC-3, DU-145 cells and HUVECs $\left(5 \times 10^{5}\right.$ cells/well) were cultured in six-well plates for $24 \mathrm{~h}$ and treated with 1 and $2.5 \mathrm{mg} / \mathrm{mL}$ of SAW for $24 \mathrm{~h}$ with fresh medium. After the treatment, cells were fixed in $70 \%$ ethyl alcohol (EtOH) and stored at $-20{ }^{\circ} \mathrm{C}$ for at least three hours. Fixed cells were washed with cold PBS and centrifuged at $2000 \times \mathrm{g}$ for 5 minutes and stained using a Muse ${ }^{\mathrm{TM}}$ Cell Cycle Kit (Merck Millipore) for 30 minutes in dark conditions. After the staining, analysis was done by Muse ${ }^{\mathrm{TM}}$ Cell Analyzer (Merck Millipore). Each experiment was performed in three replicates for each cell line. 


\section{Acridine Orange Staining}

Cellular morphology of PC-3, DU-145 cells and HUVECs was analyzed with Acridine Orange staining. For this purpose, $5 \times 10^{5}$ cells/well were cultured in six-well plates for $24 \mathrm{~h}$ and treated with 1 and $2.5 \mathrm{mg} / \mathrm{mL}$ of SAW for $24 \mathrm{~h}$. After incubation, cells were fixed and stained by adding $500 \mu \mathrm{L}$ of acridine orange for 30 minutes in the dark and examined with EVOS FL Cell Imaging System (Thermo).

\section{In vitro Angiogenesis Assays}

PC-3 and DU-145 cells that were treated with SAW and untreated control cells were replaced with starvation medium (RPMI without FBS). Cells were starved overnight and supernatants were collected and used for stimulation of HUVECs in tube formation (2D angiogenesis) and migration assays.

The tube formation assay was performed on a 48-well tissue culture dish that was coated with $150 \mu \mathrm{l}$ growth factor-reduced Matrigel (BD) that was left to solidify at $37^{\circ} \mathrm{C}$ for $30 \mathrm{~min} .25,000$ HUVECs were resuspended in the subsequent starvation media of the tumor cells and seeded on Matrigel-coated wells. Bright field images of capillary-like tubes were taken after $8 \mathrm{~h}$ of incubation at $37^{\circ} \mathrm{C}$. The mean branch points were quantified using Image J.

Boyden chamber migration assay was run on transwell inserts ( $5 \mu \mathrm{m}$ pore size- Corning) that were coated with $0.1 \%$ gelatin for 10 minutes at $37{ }^{\circ} \mathrm{C}$ then washed with PBS. HUVECs were suspended in media supplemented with $0.1 \%$ FBS and were seeded onto the transwell inserts. Migration of HUVECs was stimulated with the control and SAW treated cells' starvation media in 
the lower well. HUVECs were allowed to migrate for $16 \mathrm{~h}$. At the end of the assay, supernatants were aspirated, transwell inserts were washed with PBS and fixed with ice-cold methanol. HUVECs were stained with Hoechst dye to visualize the migrated cells. Nuclei were quantified using Image J.

\section{Statistical Analysis}

All data was statistically evaluated by SPSS 22.0. Data were expressed as a mean \pm SD of three experiments. The Analysis of Variance (ANOVA) test by Tukey's test was conducted for multiple comparison. $p<0.05$ was considered to be statistically significant.

\section{Results}

\section{The Cytotoxic Effects of SAW}

WST-1 analysis was performed to evaluate the cytotoxic effects of SAW on PC-3, DU-145 cells and HUVECs (Figure 1). Viability of PC-3 and DU-145 cells were decreased in a dose-dependent manner. When PC-3 and DU-145 cells were treated with $1 \mathrm{mg} / \mathrm{mL}$ of SAW, the viability of cells significantly reduced to $51.44 \%, 58.55 \%$, respectively for $24 \mathrm{~h}(\mathrm{p}<0.05)$. However, $69.19 \%$ and $61.88 \%$ inhibition were found in PC-3 and DU-145 cells, respectively at $2.5 \mathrm{mg} / \mathrm{mL}$ for $24 \mathrm{~h}$. The proliferation of HUVECs was reduced to $84.0 \%$ and $72.27 \%$ at 1 and $2.5 \mathrm{mg} / \mathrm{mL}$ of SAW for $24 \mathrm{~h}$. Therefore, SAW treatment was found to be much more effective in inhibiting viability of PC-3 cells than DU-145 cells and it didn't affect viability of HUVECs much in $24 \mathrm{~h}$. Viability experiment revealed that, the most effective doses of SAW were 1 and $2.5 \mathrm{mg} / \mathrm{mL}$ administrated for $24 \mathrm{~h}$, therefore these doses were selected for further analysis. 


\section{Apoptotic Effects of SAW}

Annexin V analysis was conducted in order to determine the apoptotic effects of SAW on PC-3, DU-145 cells and HUVECs (Figure 2). Particularly, SAW significantly induced apoptosis in PC-3 and DU-145 cells after treatment of SAW ( 1 and $2.5 \mathrm{mg} / \mathrm{mL})(p<0.05)$. The percentage of total apoptotic cells was remarkably increased to $77.65 \%$ and $66.25 \%$ in PC-3 and DU-145 cells, respectively at $2.5 \mathrm{mg} / \mathrm{mL}$ of SAW for $24 \mathrm{~h}$ compared to the control group $(p<0.05)$. Furthermore, the proportion of total apoptotic cells was $19.69 \%$ and $26.31 \%$ at 1 and $2.5 \mathrm{mg} / \mathrm{mL}$ of SAW, respectively in HUVECs. The obtained results show that SAW caused apoptotic cell death and these findings were consistent with the results of WST-1 analysis.

\section{Cell Cycle Arrest}

Results of the cell cycle arrest analyses indicated that SAW treatment (1 and $2.5 \mathrm{mg} / \mathrm{mL}$ ) resulted in G0/G1 arrest in PC-3, DU-145 and HUVECs (Figure 3). The percentage of PC-3, DU145 cells and HUVECs in the G0/G1 phase were considerably increased to $92.6 \%, 89.5 \%$ and $75.3 \%$ at $2.5 \mathrm{mg} / \mathrm{mL}$ SAW concentrations compared to the control group $(63.0 \%, 65.2 \%$ and $63.4 \%)$, respectively $(p<0.05)$ (Figure $3 A$ and $3 B$ ). Therefore, our findings showed that SAW treatment significantly accumulated cells in the G0/G1 phase arrest and induced apoptotic cell death.

\section{Cell Morphology}

The changes in the morphology of PC-3, DU-145 and HUVECs after treatment of SAW were determined by acridine orange staining (Figure 4). Apoptotic bodies and chromatin 
condensation were observed in PC-3 and DU-145 cells and some of the cells indicated necrotic morphology in response to SAW treatments. Cytoplasmic shrinkage and more round shape were only observed at $2.5 \mathrm{mg} / \mathrm{mL}$ concentration of SAW in PC-3 and DU-145 cells. Additionally, there were no specific morphological changes observed in HUVECs following incubation with SAW. However, there were some apoptotic bodies and necrotic cells. Consequently, PC-3 cells were more sensitive to SAW treatment than DU-145 cells and SAW treatment didn't affect HUVECs morphology.

\section{Inhibition of Tumor Cell Induced Angiogenesis}

Boyden chamber migration assay showed that there were significantly less migrated HUVECs towards the supernatants of SAW treated PC-3 and DU-145 cells compared to control cells' (Figure 5A-B). Moreover, 2D angiogenesis assay revealed that supernatants of SAW treated PC-3 and DU-145 significantly inhibited number of branch points HUVECs made on the matrigel matrix compared to control cells' supernatants (Figure 5C-D). Taken together, these two experiments show that tumor cell secreted angiogenic factor(s) that induce angiogenesis was blocked by the SAW treatment.

\section{Discussion}

In the current study, SAW's anti-cancer effects were investigated on metastatic prostate cancer cell lines, for the first time. Our findings demonstrated that SAW induced apoptotic cell death and cell cycle arrest and suppressed cell viability in metastatic prostate cancer cells and their ability to induce angiogenesis, in vitro. 
SAW is a high alkaline mineral water which contains different minerals including $\mathrm{Na}$ and $\mathrm{Mg}$ and may have anti-cancer effects due to its rich mineral content. $\mathrm{Na}$ and $\mathrm{Mg}$, the most abundant minerals in the body, have been shown to regulate glucose metabolism, inflammation, and cell proliferation [16]. Thus $\mathrm{Na}$ and $\mathrm{Mg}$ are involved in a large number of biological processes, so the lack of these minerals can affect many processes including tumor progression. Low concentration of $\mathrm{Mg}$ is associated with an increase risk of various diseases such as cancer [17]. For example, intake of magnesium has been reported to be protective against colorectal cancer progression [18].

PC-3 and DU-145 cell lines are both androgen receptor (AR) positive prostate adenocarcinoma cell lines. PC-3 cells have more metastatic potential than DU-145 cells. PC-3 cells are obtained from bone metastasized prostate cancer whereas DU-145 cells are derived from brain metastasis and these cells do not express prostate specific antigen [19]. These two prostate cell lines have different genetic backrounds. PC-3 cells are found to carry deletion at codon 138 in TP53 gene associated with loss of a 17p (hemizygous 17p) whereas DU-145 cells have two mutations in TP53 gene [20]. Thus, genetic background and origin may cause differences in responses of PC-3 and DU-145 cells against therapeutic agents and this may also be the reason why two cell lines respond differently to SAW.

Growing tumor mass needs oxygen and nutrients and vasculature surrounding the tumor is not sufficient to replenish the tumor cells after tumor reaches a size of approximately $1 \mathrm{~mm}^{3}$. In order to make their own vasculature tumor cells secrete angiogenic factors that derive the formation of new tumor vasculature from the existing vessels of the organ. Tumor cells not only use new vasculature to get oxygen and nutrients but they can also use this newly formed 
vasculature as a route for metastatic dissemination. Tumor cells in vitro also secrete these angiogenic factors especially when the cells are nutrient deprived. Therefore, we used the starvation medium of SAW treated PC-3 and DU-145 cells to stimulate HUVECs in migration and tube formation experiments and found out that SAW treatment of tumor cells significantly inhibits tumor induced angiogenesis in vitro. One of the main molecules that derive angiogenesis is VEGF-A that is triggered by hypoxia and it is expressed by both PC-3 and DU-145 cells [21]. SAW may inhibit angiogenesis by inhibiting release of this growth factor by the tumor cells.

In conclusion, our findings showed that SAW had a significant suppressive effect on cell proliferation, tumor derived angiogenesis and it induced apoptotic cell death in prostate cancer cells. However, the molecules responsible for its apoptotic effects and the inhibition of tumor derived angiogenesis need to be further investigated mechanistically. Thus, SAW might be potentially promising therapy for treatment of metastatic prostate cancer.

\section{Acknowledgements}

We thank Mr. Faruk Durukan for the preparation of SAW.

\section{References}

1. Mohile SG, Shelke AR: Treating prostate cancer in elderly men: how does aging affect the outcome? Curr Treat Options Oncol 2011, 12:263-275

2. Bosland MC: The role of steroid hormones in prostate carcinogenesis. J Natl Cancer Inst Monogr 2000, 27:39-66

3. Crawford E: Epidemiology of prostate cancer. Urology 2003, 62:3-12.

4. Gronberg H: Prostate cancer epidemiology. Lancet 2003, 361:859-864 
5. Whittemore AS, Kolonel LN, Wu AH, John EM, Gallagher RP, Howe GR: Prostate cancer in relation to diet, physical activity, and body size in blacks, whites, and Asians in the United States and Canada. J Natl Cancer Inst 1995, 87:652-661

6. Durlach, J., Bara, M., Guiet-Bara, A., and Colley, P. 1986. Relationship between magnesium, cancer and carcinogenic or anticancer metals. Anticancer Res. 6:1353-1362

7. Durlach, J., Bara, M., and Guiet-Bara, A. 1990. Magnesium and its relationship to oncology. Metal Ions Biol. System 26:549-578

8. Blondell, J. M. 1980. The anticarcinogenic effect of magnesium. Med. Hypoth. 6:863-871

9. Yang, C. Y., Chiu, H. F., Chiu, J. F., Tsai, S. S., and Cheng, M. F. 1997. Calcium and magnesium in drinking water and risk of death from colon cancer. Jpn. J. Cancer Res. 88:928-933

10. Yang, C. Y., Cheng, M. F., Tsai, S. S., and Hsieh, Y. L. 1998. Calcium, magnesium and nitrate in drinking water and risk of death from gastric cancer. Jpn. J. Cancer Res. 89:124-130

11. Yang, C. Y., Chiu, H. F., Cheng, M. F., Tsai, S. S., Hung, C. F., and Tseng, Y. T. 1999. Pancreatic cancer mortality and total hardness levels in Taiwan's drinking water. J. Toxicol. Environ. Health $56: 361-369$

12. Drobnik M. [Evaluation of pharmacodynamic properties of medium-mineralized alkaline water designed for distribution as bottled natural mineral water]. Rocz Pań stwowego Zakładu Hig 2000;51:379-84

13. Gasbarrini G, Arienti V, Magri F, et al. [Effects of bicarbonatedalkaline water (Uliveto) on gastric and gallbladder emptying in normal subjects. Ultrasonic evaluation]. Minerva Med $1991 ; 82: 59-62$

14. Lendowski L, Färber H, Holy A, et al. Accidental contamination of a German town's drinking water with sodium hydroxide. Int J Hyg Environ Health 2015;218:366-9

15. Fenton TR, Huang T Systematic review of the association between dietary acid load, alkaline water and cancer BMJ Open 2016;6:e010438 
16. Gröber, U., Schmidt, J., \& Kisters, K. (2015). Magnesium in Prevention and Therapy. Nutrients, 7(9), 8199-8226

17. Vormann, J., (2016) Magnesium: nutrition and homoeostasis. AIMS Public Healt 3:329-340

18. Hou N, Huo D, Dignam JJ (2013) Prevention of colorectal cancer and dietary management. Chin Clin Oncol 2:13

19. Alimirah F, Chen J, Basrawala Z, Xin H, Choubey D (April 2006). "DU-145 and PC-3 human prostate cancer cell lines express androgen receptor: implications for the androgen receptor functions and regulation". FEBS Lett. 580 (9): 2294-300

20. Carroll AG, Voeller HJ, Sugars L, Gelmann EP. p53 oncogene mutations in three human prostate cancer cell lines. Prostate. 1993;23(2):123-34

21. Harper ME., Glynne JE, Goddard L, Thurston VJ, Griffiths K Vascular endothelial growth factor (VEGF) expression in prostatic tumours and its relationship to neuroendocrine cells. Br. J. Cancer 1996;74: 910-916 
bioRxiv preprint doi: https://doi.org/10.1101/2019.12.15.877233; this version posted December 16, 2019. The copyright holder for this preprint (which was not certified by peer review) is the author/funder, who has granted bioRxiv a license to display the preprint in perpetuity. It is made available under aCC-BY-NC-ND 4.0 International license.

Table.1. Mineral and trace element content of stone alkaline water (SAW)

\begin{tabular}{|l|l|}
\hline \multicolumn{1}{|c|}{ Content } & \multicolumn{1}{|c|}{ Measured Values } \\
\hline Barium & $0,368 \mathrm{mg} / \mathrm{L}$ \\
\hline Nickel & $0,012 \mathrm{mg} / \mathrm{L}$ \\
\hline Magnesium & $4,25 \mathrm{mg} / \mathrm{L}$ \\
\hline Iron & $<5 \mu \mathrm{g} / \mathrm{L}$ \\
\hline Copper & $<1 \mu \mathrm{g} / \mathrm{L}$ \\
\hline Chromium & $<2 \mu \mathrm{g} / \mathrm{L}$ \\
\hline Sodium & $2,8 \mathrm{~g} / \mathrm{L}$ \\
\hline Sulfate & $0,25 \mathrm{~g} / \mathrm{L}$ \\
\hline Carbonate & $0,1 \mathrm{~g} / \mathrm{L}$ \\
\hline Quicksilver & Not found \\
\hline Arsenic & Not found \\
\hline Cyanide & Not found \\
\hline Flor & Not found \\
\hline Cadmium & $3,45,5 \mathrm{~g} / \mathrm{L} / \mathrm{cm}{ }^{3}$ \\
\hline Total solids & \\
\hline Density & \\
\hline
\end{tabular}


A

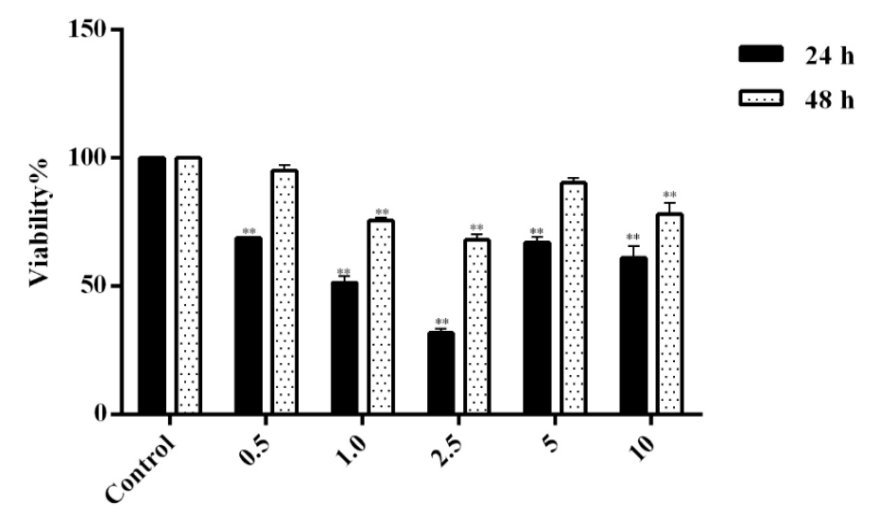

B

Concentration of SAW $(\mathrm{mg} / \mathrm{mL})$
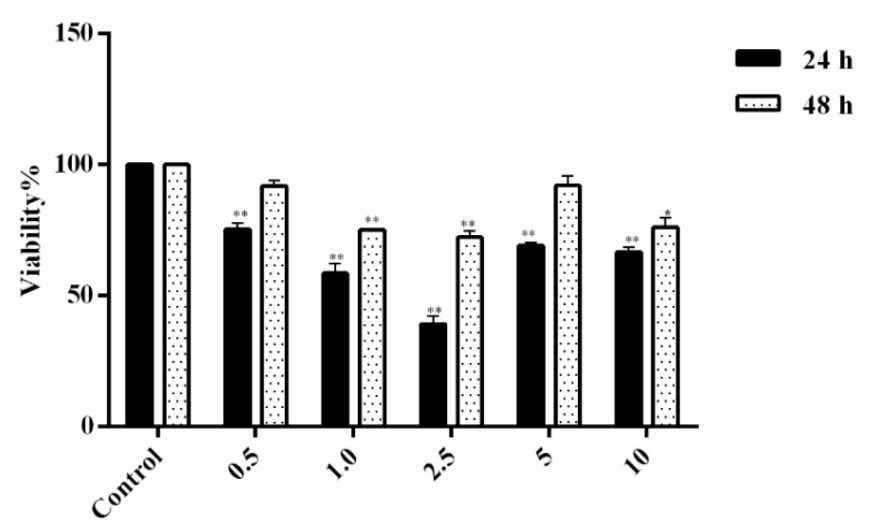

Concentration of SAW $(\mathrm{mg} / \mathrm{mL})$

C

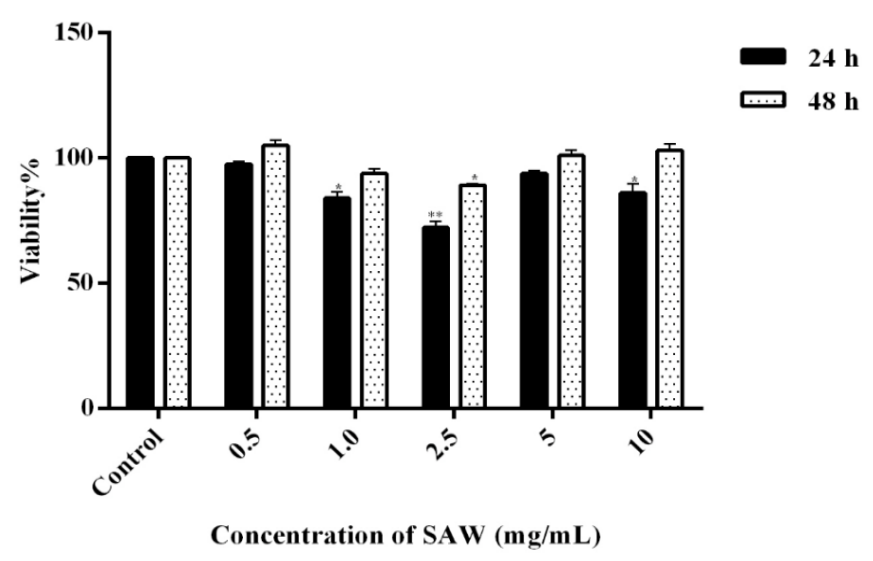

Figure 1. The viability of (A) PC-3, (B) DU-145 and (C) HUVEC cells exposed to 0.5-10 mg of SAW for 24 and 48 hours. $\left(p<0.05^{*}, p<0.01^{* *}\right)$. 


\section{PC-3}
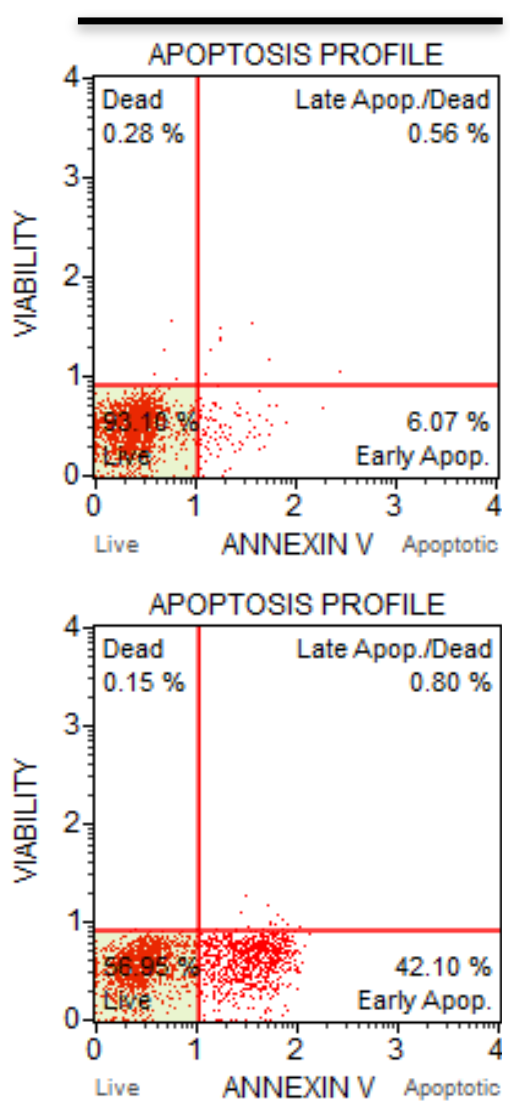

(c)

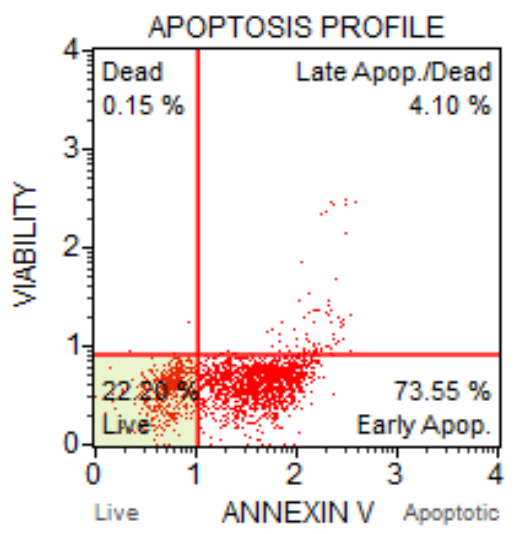

\section{DU-145}
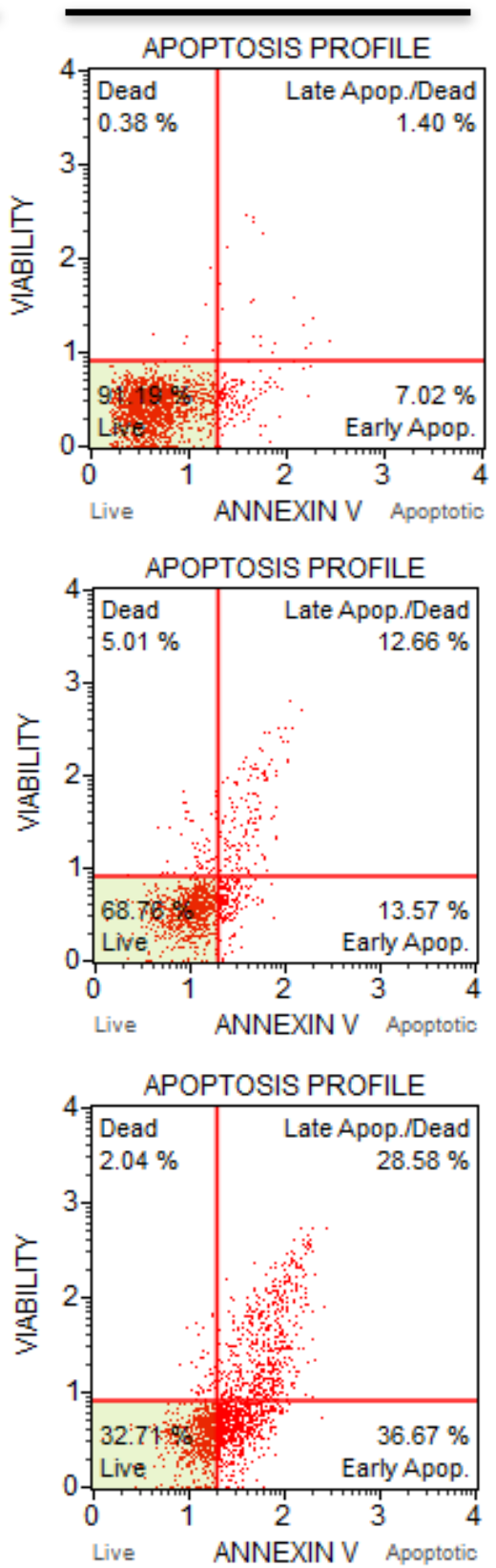

HUVEC
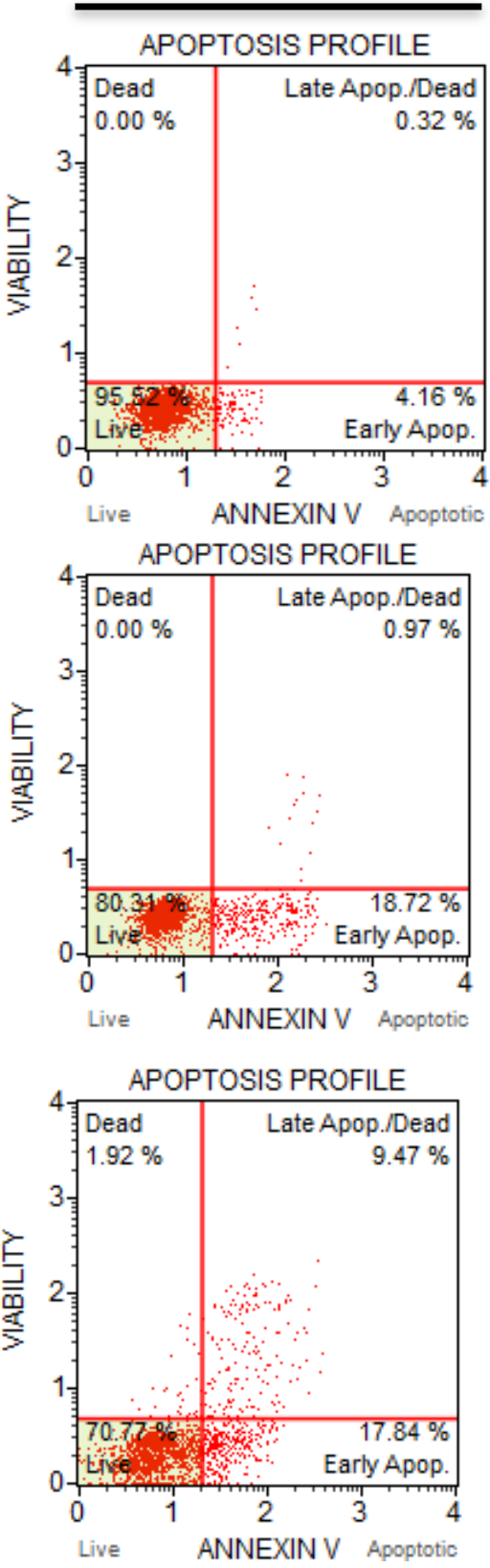

Figure 2. Annexin $V$ analysis. of PC-3, DU-145 and HUVECs exposed to (b) $1 \mathrm{mg} / \mathrm{mL}$ and (c) 2.5 $\mathrm{mg} / \mathrm{mL}$ of SAW for 24 hours compared with (a) control. 
A

(a)

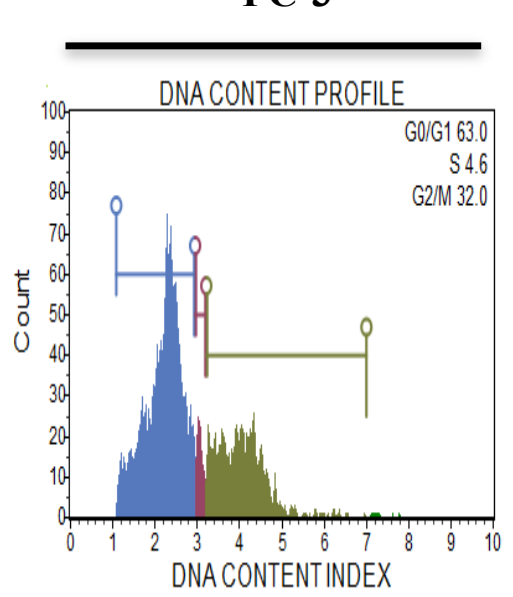

(b)

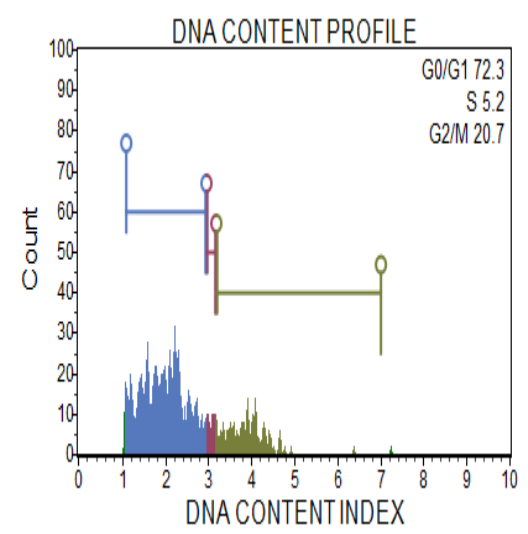

(c)

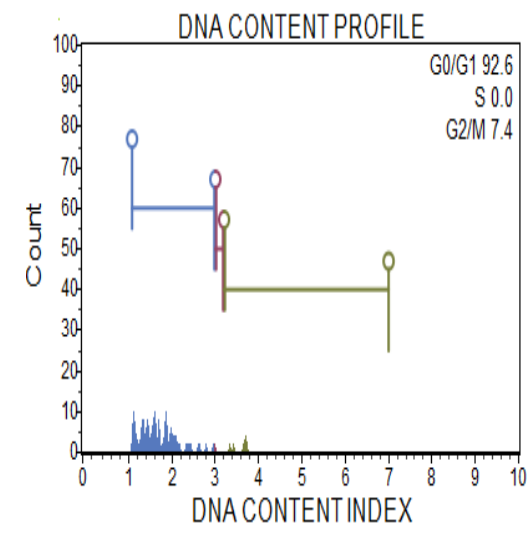

DU-145
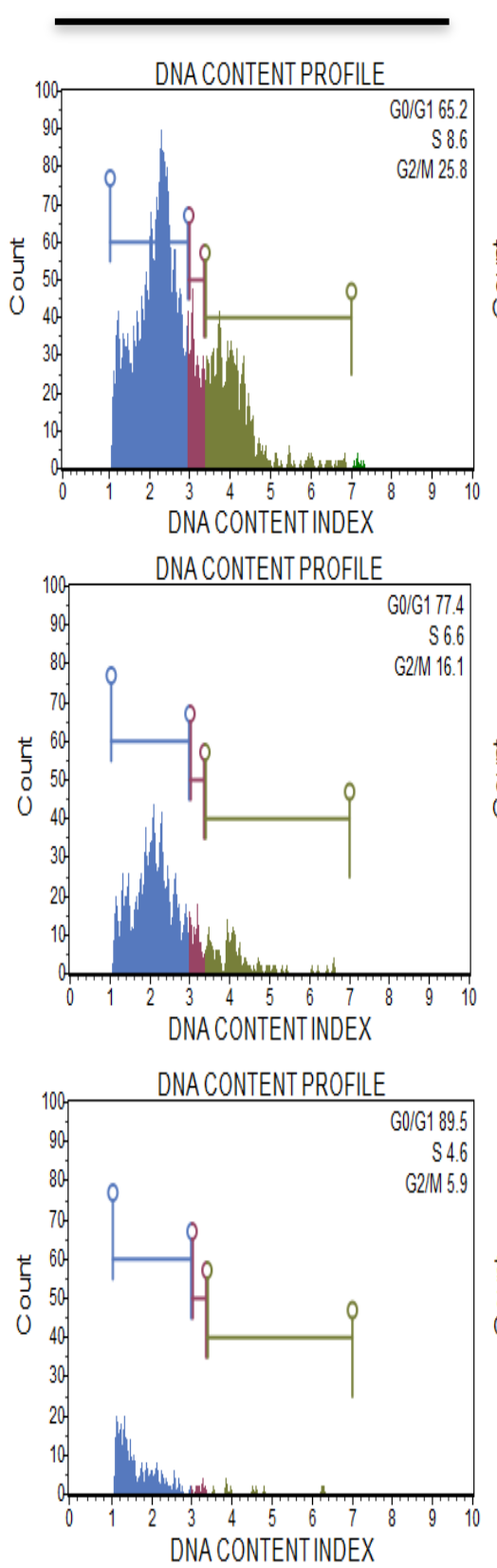

HUVEC
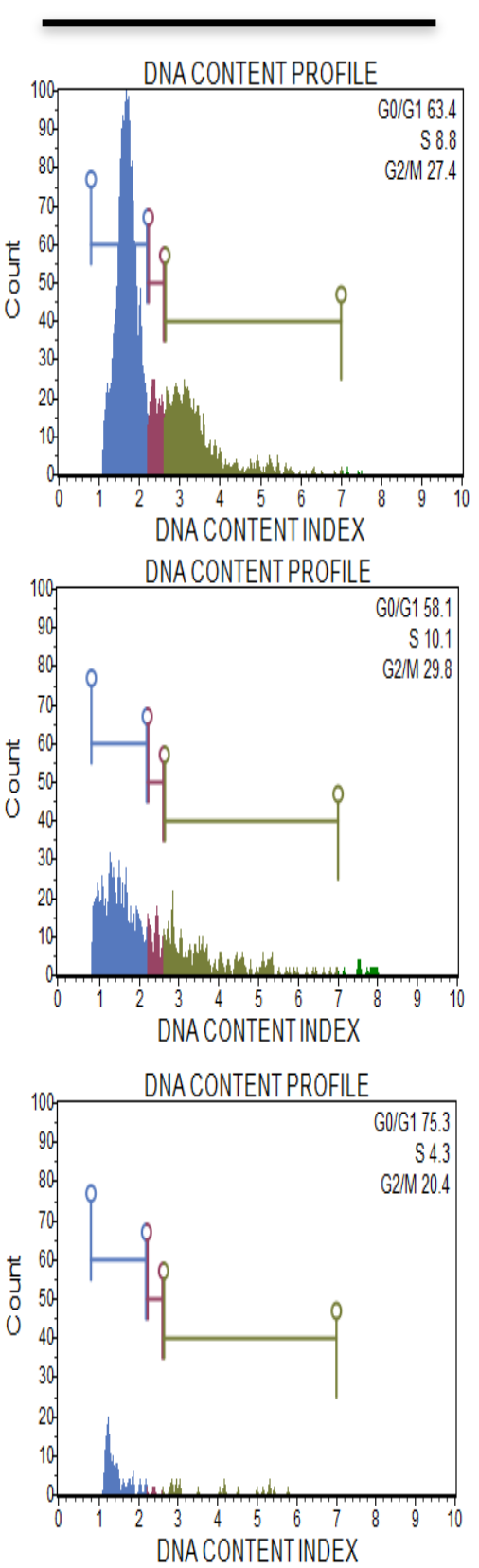


\section{B}
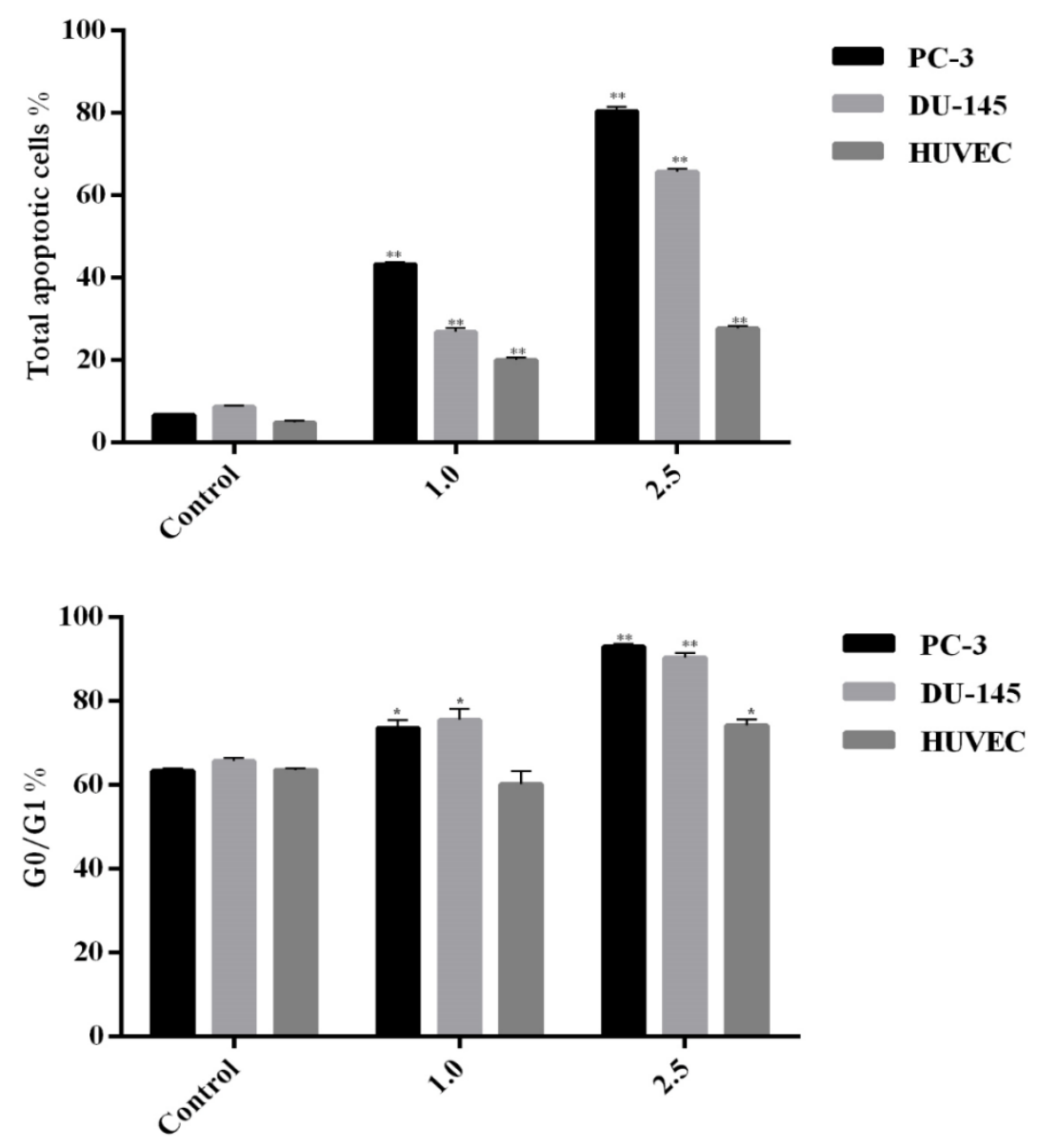

Figure 3. (A) Cell cycle analysis of PC-3, DU-145 and HUVECs following incubation with (b) 1 and (c) $2.5 \mathrm{mg} / \mathrm{mL}$ of SAW for 24 hours compared with control (a). (B) total apoptotic cell amount and accumulation of G0/G1 arrest in response to SAW in PC-3, DU-145 and HUVEC cells $\left(p<0.05^{*}\right.$, $\left.\mathrm{p}<0.01^{* *}\right)$. 
(a)
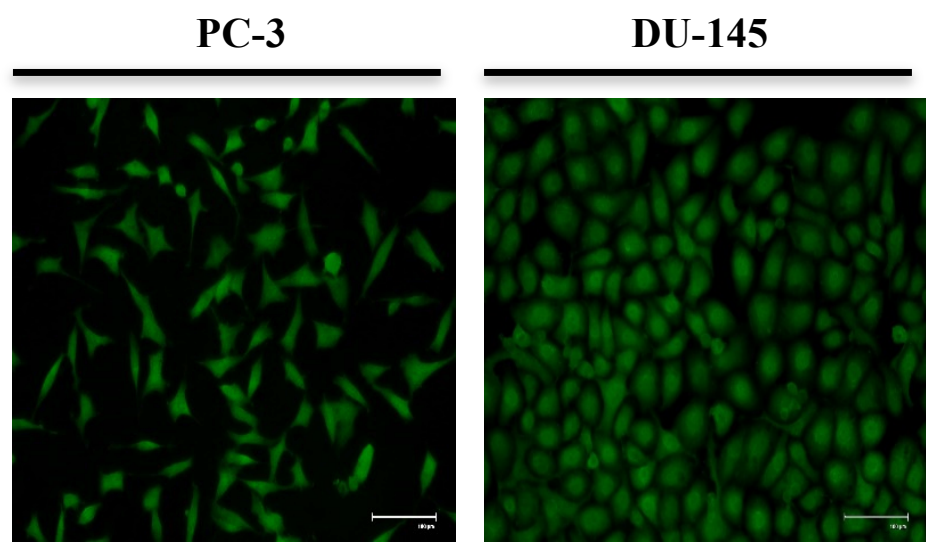

\section{HUVEC}
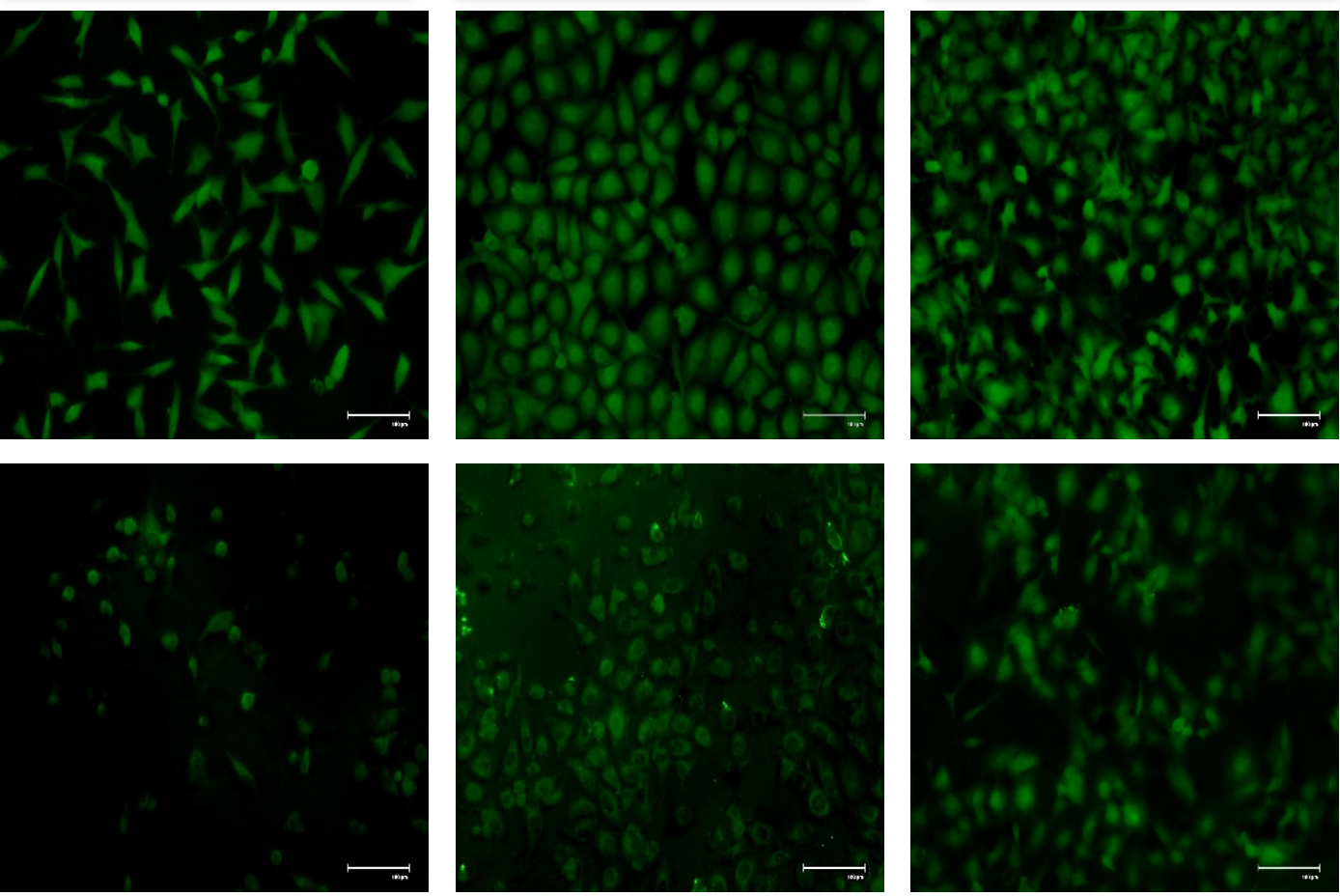

(b)
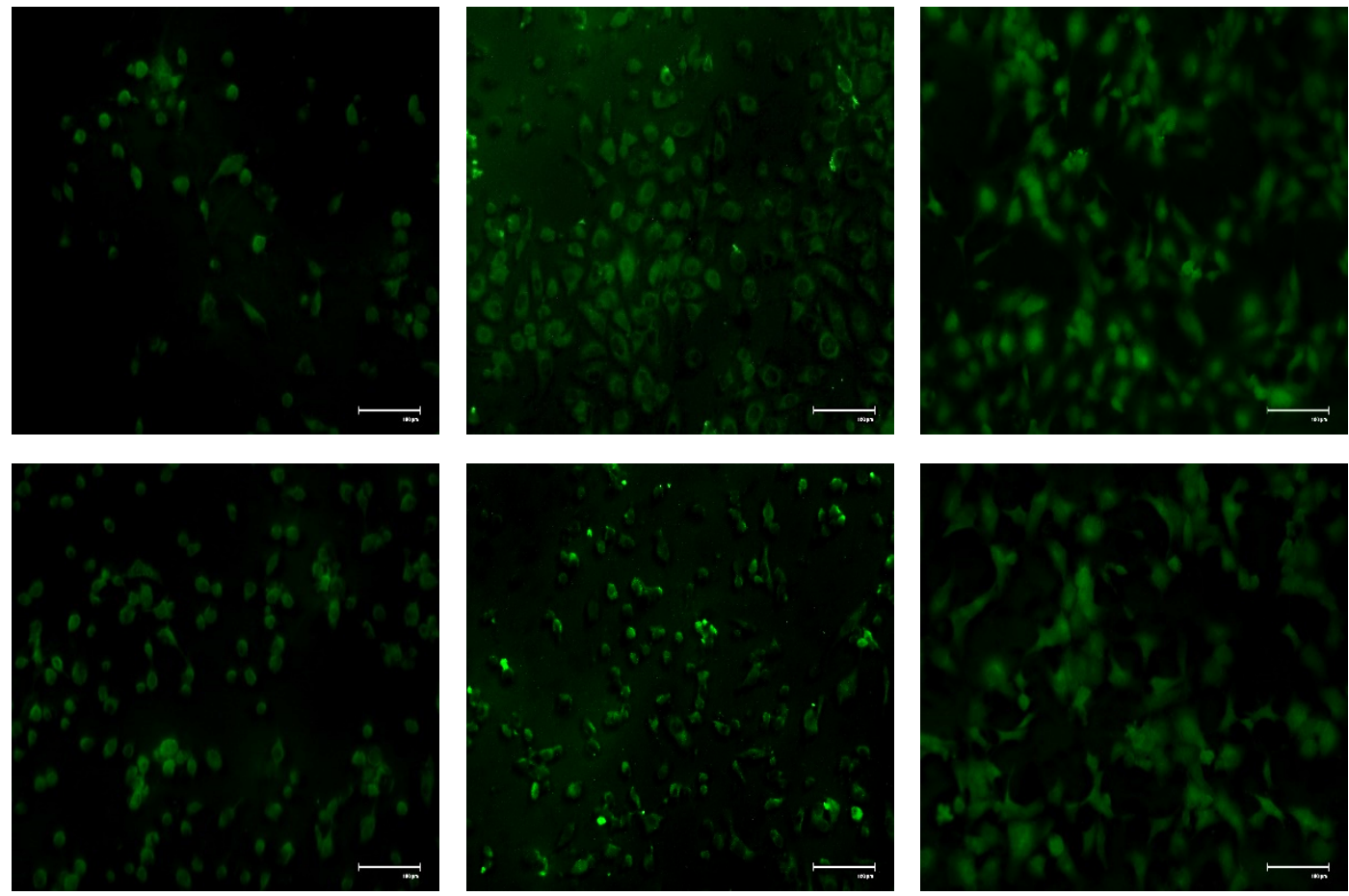

(c)

Figure 4. Acridine Orange staining of PC-3, DU-145 and HUVECs: a) control b) $1 \mathrm{mg} / \mathrm{mL}$ and c) 2.5 $\mathrm{mg} / \mathrm{mL}$ SAW for 24 hours. Scale bar: $100 \mu \mathrm{m}$ 
A

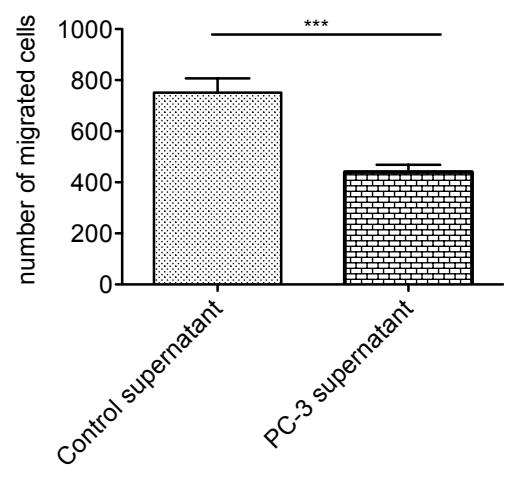

C

Control supernatant

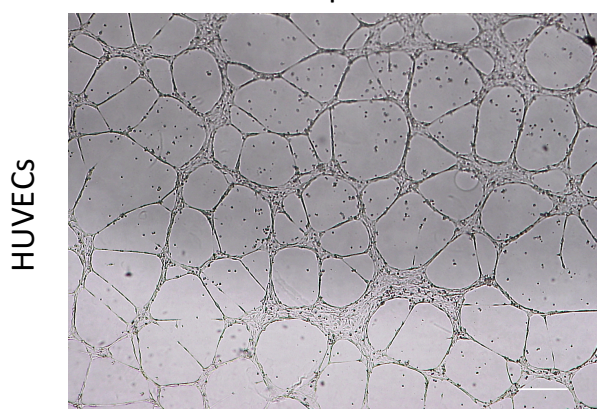

Control supernatant

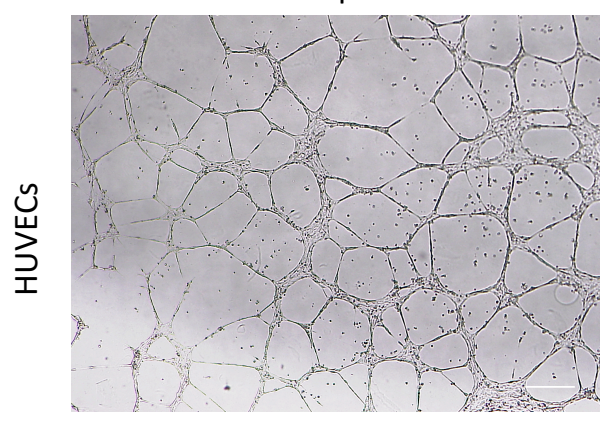

B

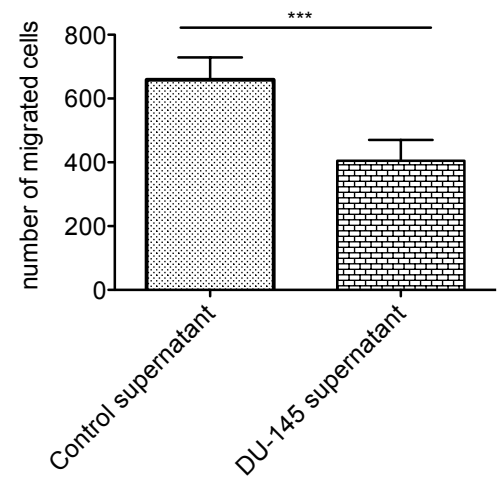

PC-3 supernatant

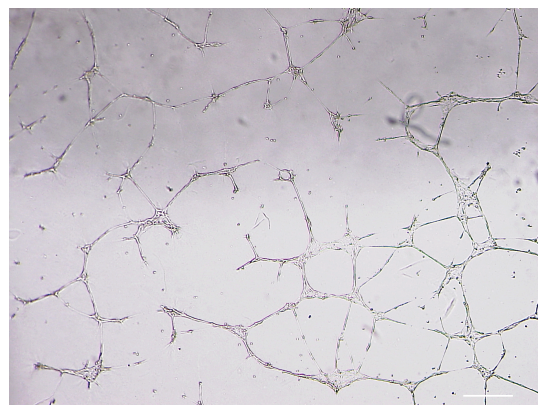

DU-145 supernatant

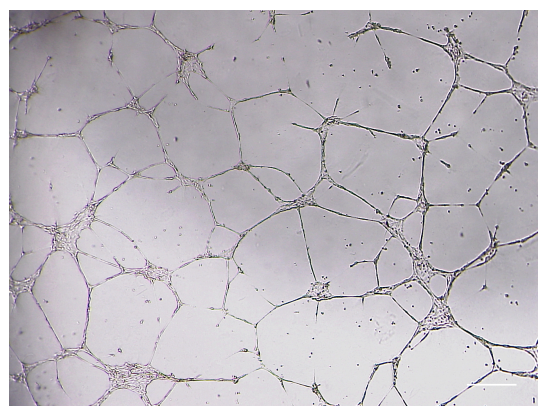

D
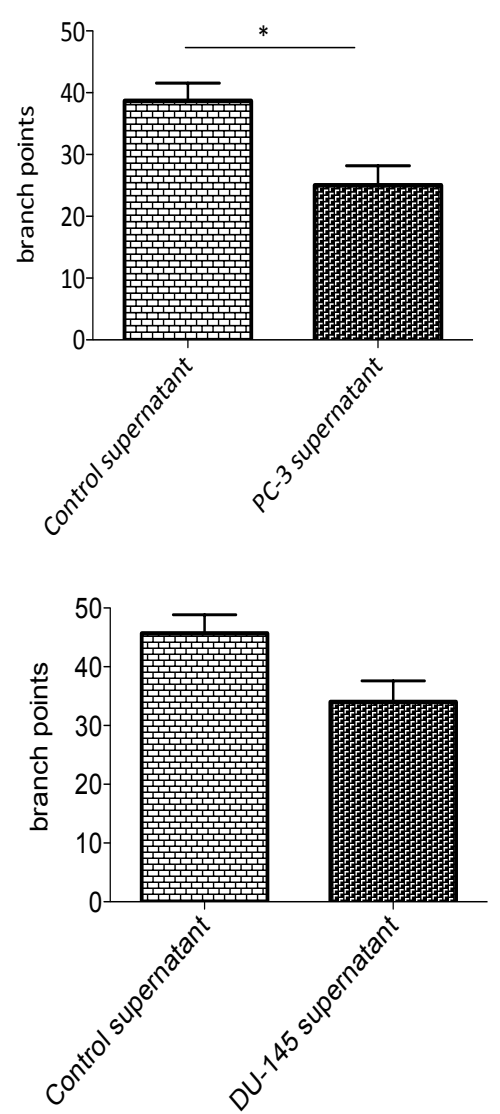

Figure 5: HUVECs functional assays with conditioned medium of SAW treated PC-3 and DU-145 cells. A. Migration of HUVECs stimulated with control and SAW treated PC-3 cells B. Migration of HUVECs stimulated with control and SAW treated DU-145 cells C. Light microscope pictures of HUVECs forming tubes in 2D angiogenesis assay stimulated with control and SAW treated PC-3 and DU-145 cells D. Number of branchpoints HUVECs make with conditioned medium of control and SAW treated PC-3 cells E. Number of branchpoints HUVECS make with conditioned medium of control and SAW treated Du-145 cells ( $\left.p<0.05^{*}, p<0.01^{* *}\right)$, Scale bar: $50 \mu \mathrm{m}$ 